\title{
Penanggulangan Tingkat Kenakalan Remaja Dengan Bimbingan Agama Islam
}

\section{Suparman Mannuhung ${ }^{1}$}

${ }^{1}$ Email: mzaid090609@gmail.com Dosen Universitas Andi Djemma

\begin{abstract}
Abstrak. Fenomena sosial yang kerap terjadi dan mengganggu ketertiban di tengahtengah masyarakat diantaranya adalah kenakalan remaja termasuk perilaku menyimpang yang berujung dengan tindakan kriminal. Kenakalan remaja sering dianggap sebagai sumber masalah karena dapat merusak dan membahayakan kondisi sistem sosial. Dewasa ini kasus kriminalitas dikalangan remaja cukup memprihatinkan. Adapun metode pendekatan yang dilakukan dalam pelatihan tersebut adalah metode ceramah dan tanya jawab atau diskusi antara peserta pelatihan dengan narasumber serta metode dakwah akan dilakukan beberapa masjid di Kota Palopo. Tujuan umum kegiatan ini, yaitu: pertama, pengembangan dan peningkatan pengetahuan, sikap dan keterampilan para remaja sehingga memiliki kemampuan untuk mengkaji, merumuskan dan memiliki rasa keperdulian untuk memecahkan persoalan masyarakat berdasarkan sudut pandang Islam. Kedua, terintegrasikan peran perguruan tinggi, pemerintah dan masyarakat dalam upaya menjaga kedamaian ketentraman dan meningkatnya partisipasi masyarakat dalam kerukunan hidup bersama. Langkah-langkah kegiatan pengabdian masyarakat yang dilakukan yaitu tahapan persiapan, penyelenggaraan pelatihan, aplikasi/ praktek, dan evaluasi kegiatan. Adapun saran untuk kegiatan pengabdian masyarakat yaitu dengan merunitaskan kegiatan pengabdian ini yang berdampak pada perbaikan kehidupan masyarakat yang religius dan dapat meminimalisir kenakalan remaja.
\end{abstract}

Kata Kunci: Kenakalan Remaja, Perilaku Menyimpang dan Agama Islam

\section{PENDAHULUAN}

Kenakalan remaja dan perilaku menyimpang merupakan fenomena sosial yang terjadi di tengah-tengah masyarakat. Dalam perspektif teoritis bahwa kenakalan remaja merupakan pelanggaran yang dilakukan oleh remaja dan berujung pada pelanggaran yang berlebihan. Sedangkan, perilaku menyimpang terjadi karena terdapat penyimpangan perilaku dari berbagai aturan-aturan sosial ataupun dari nilai dan norma sosial yang berlaku. Kenakalan remaja dan perilaku menyimpang dapat dianggap sebagai sumber masalah karena dapat merusak dan membahayakan tegaknya sistem sosial. Salah satu contoh kenakalan remaja yang termasuk perilaku menyimpang adalah kebiasaan terlibat dalam geng motor atau juga disebut dengan begal motor. Aktivitas geng motor selalu berujung pada tindakan yang brutal dan anarkis. Begitu juga kenakalan remaja lainnya yang terkadang berakhir dengan tindakan dan perilaku kriminal yang mengganggu kehidupan sosial kemasyarakatan.

Dewasa ini kasus kriminalitas dikalangan remaja cukup memprihatinkan. Di Kota Palopo kususnya, tindakan kriminalitas setiap tahunnya cukup fluktuatif dan selalu naik turun. Berdasarkan data BPS Kota Palopo, jumlah tindakan kriminalitas dari 2003 sampai 2013, tindakan kriminalitas yang terkecil terjadi pada tahun 2007 dengan 34 kasus (Lestari, 
2015). Sedangkan yang terbesar terjadi pada tahun 2010 dengan 624 kasus. Meskipun cenderung turun sampai menyisakan 176 kasus di tahun 2013, tetapi diprediksikan akan meningkat pada tahun 2016 dan 2017, data lengkapnya sebagaimana ditunjukan pada Gambar 1 Kasus kriminal yang terjadi pada tahun 2013 tersebut memiliki rincian narkoba ada 20 kasus, pembunuhan 2 kasus, kejahatan seksual 3 kasus, penganiayaan 88 kasus, pencurian 40 kasus dan penipuan 23 kasus. Itulah kasus kriminal yang baru tercatat oleh kepolisian, masih ada kasus kriminal akibat kenakalan remaja lainnya yang belum tercatat oleh pihak kepolisian misalnya miras, tawuran yang berakhir dengan kematian, dan kasus lainnya. Salah satu alasan meningkatnya kriminalitas tersebut karena kenakalan remaja dan perilaku menyimpang serta kehidupan masyarakat yang terlalu materialistik dan individualistik serta tidak perduli terhadap sesama.

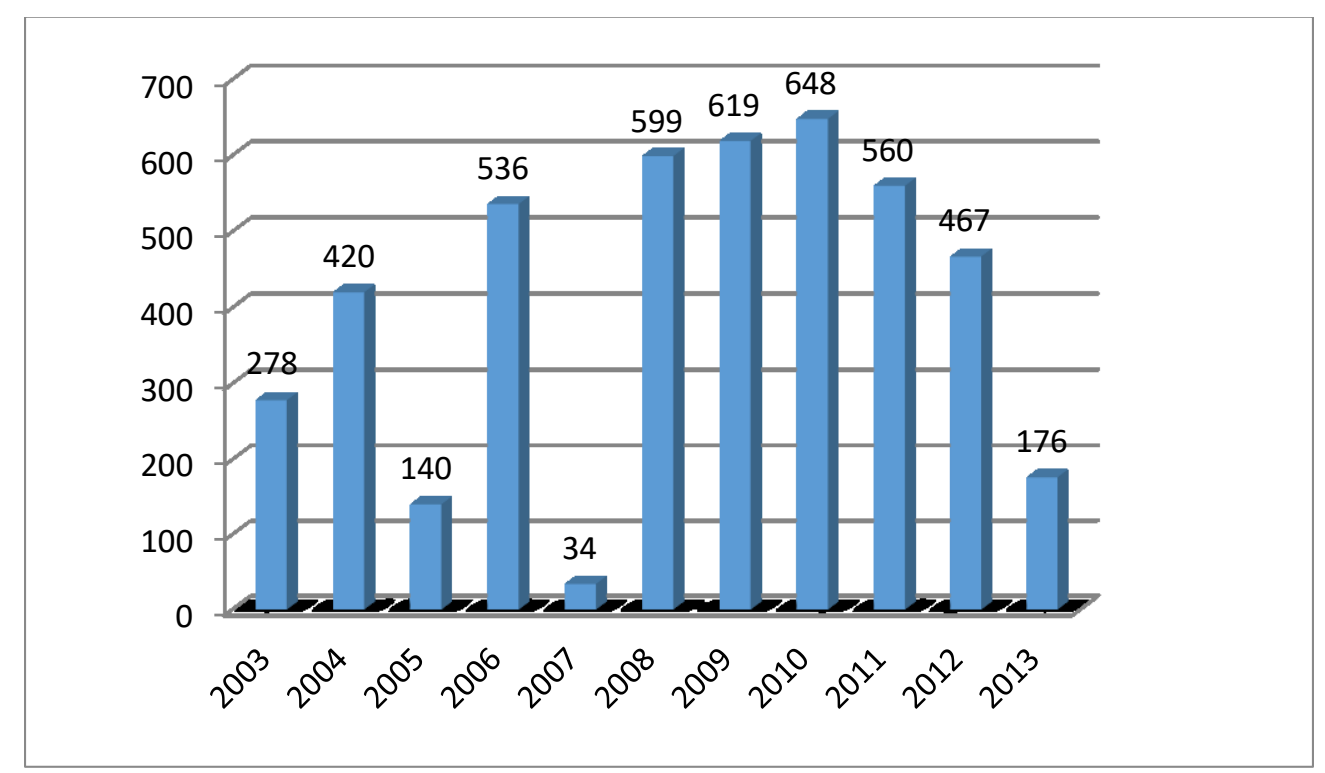

Gambar 1. Indeks Kejahatan Kriminal 2003-2013 di Kota Palopo

Kenakalan remaja atau dalam bahasa Inggris dikenal dengan istilah juvenile delinquency. Secara etimologis, istilah juvenile delinquency berasal dari dua kata yaitu juvenile yang berarti anak, dan delinquency yang berarti kejahatan. Jadi secara etimologis juvenile delinquency adalah kejahatan anak. Dari berbagai pengertian tentang kenakalan remaja dapat disimpulkan bahwa kenakalan remaja memiliki arti kejahatan yang dilakukan oleh anak-anak diusia remaja. Sehingga, bisa diartikan juga bahwa kenakalan remaja merupakan gejala patologis sosial pada remaja yang disebabkan oleh satu bentuk pengabaian terhadap kondisi sosial kemasyarakatan. Akibatnya, mereka mengembangkan bentuk perilaku yang menyimpang (Kartono, 2007). Kenakalan remaja merupakan kumpulan dari berbagai perilaku remaja yang tidak dapat diterima secara sosial hingga terjadi aktifitas yang berujung pada tindakan pelanggaran (kriminal).

Para ahli membagi kenakalan remaja kedalam tiga tingkatan yaitu (1) kenakalan biasa seperti remaja yang suka berkelahi, suka keluyuran, bolos sekolah, pergi dari rumah tanpa pamit. (2) kenakalan yang menjurus pada pelanggaran dan kejahatan seperti mengendarai mobil tanpa SIM, mengambil barang orang tua tanpa izin, dan (3) kenakalan khusus seperti 
penyalahgunaan narkotika, hubungan seks diluar nikah, pemerkosaan dan lain-lain. Kategori tersebut telah menjadi ukuran kenakalan remaja dalam berbagai penelitian ilmiah.

Sedangkan perilaku menyimpan yaitu untuk menentukan paling tidak ada tiga perspektif yang harus diketahui yaitu absolutist, normative, dan reactive. Perspektif absolutist berpendapat bahwa kualitas atau karakteristik perilaku menyimpang bersifat instrinsik, terlepas dari bagaimana ia dinilai. Dengan kata lain, perilaku menyimpang ditentukan bukan dengan norma, kebiasaan, adat atau aturan-aturan sosial. Dalam perspektif normative berpendapat bahwa perilaku menyimpang bisa didefinisikan sebagai setiap perilaku yang tidak berhasil dan tidak mmampu menyesuaikan diri dengan kehendak masyarakat atau kelompok tertentu dalam masyarakat. Dalam perspektif reactive berpandangan bahwa perilaku menyimpang dapat ditemukan dalam penilaian perilaku tersebut secara actual (Kartono, 2007).

Merton Cullen \& Agnew menyebutkan ada empat penyebab terjadi perilaku menyimpang, yaitu (1) inovasi merupakan perilaku seseorang menerima atau mengakui tujuan yang selaras dengan budaya atau diinginkan masyarakat. (2) Ritualisme terjadi apabila seseorang menerima cara-cara yang diperkenankan secara budaya (culture) tetapi menolak atau mengganti tujuan sehingga berbeda dengan harapan semula dari masyarakat atau kelompok. (3) Pengasingan diri (retreatment) terjadi jika seseorang menolak atau tidak mengakui lagi baik cara maupun tujuan yang diperkenankan secara budaya tanpa menggantinya dengan yang baru. 4) Pemberontakan (rebellion) terjadi manakala seseorang menolak baik cara maupun tujuan yang diperkenankan secara budaya dengan menggantikannya dengan yang baru (Yusuf, 2008).

Kenakalan remaja dan perilaku menyimpang terjadi akibat dari semakin merosotnya nilai-nilai ketakwaan yang dimiliki individu, kurangnya pemahaman agama di tengah masyarakat dan kurangnya pemahaman tentang kehidupan yang penuh kedamaian (rasa aman) serta adanya pengaruh negatif dari arus globalisasi termasuk penyalahgunaan teknologi informasi dan komunikasi (TIK) yang salah kaprah. Penggunaan TIK tersebut sebagai konsekuensi dari tidak adanya sikap dan perilaku selektif dalam menerima dan menggunakan berbagai informasi dan komunikasi yang menguntungkan (Hadis, 2014).

Berbagai bentuk kenakalan remaja dan perilaku menyimpang pada umumnya disebabkan oleh proses belajar meniru model yang keliru terhadap berbagai tayangan yang dilihat melalui layar lebar di bioskop, acara-acara di televisi, di internet, di majalah, di surat kabar, bulletin, di berbagai media cetak dan elektronik serta media on line lainnya. Sebagai contoh, maraknya kasus narkoba dikalangan diremaja dikota Palopo tahun 2016 sebanyak 82 kasus bahkan masuk peringkat kedua pengguna narkoba di Sulawesi Selatan (Palopo Post, 31 Agustus 2016). Kasus pembunuhan akibat konsumsi minuman keras dikalangan remaja, kasus pergaulan bebas dikalangan remaja kerap terjadi bahkan Kapolres Kota Palopo cukup prihatin dengan kasus tersebut (Palopo Post, 3 Januari 2017), kekerasan di sekolah dan di tengah masyarakat, pelecehan seksual di sekolah, kasus suka kepada sesama jenis (homo dan lesbi), terlibat tawuran antar kelompok remaja (antar SMA), pencurian 
motor, penjambretan/ perampasan, pencurian uang tunai dan barang berharga dan kasus kriminal lainnya yang terjadi di Kota Palopo.

Harus diakui bahwa upaya preventif terjadinya kenakalan remaja dan perilaku menyimpang yang berujung pada tindakan kriminalitas, bukan hanya tugas aparat kepolisian dan psikolog saja, akan tetapi sangat jelas menjadi tugas semua pihak termasuk orang tua, guru dan masyarakat pada umumnya. Oleh karena itu, untuk mengatasi berbagai bentuk kenakalan remaja dan perilaku menyimpang dikalangan remaja, salah satu cara yang ampuh untuk mengatasi persoalan tersebut ialah menuntun mereka untuk selalu berbuat kebaikan dan kembali ke jalan yang benar serta menjauhi tindakan keji dan mungkar sebagaimana tuntunan al-Qur'an dan al-Hadits yang menjadi petunjuk bagi kita semua (Kementerian Agama RI, 2013). Untuk itu maka sangat diperlukan dan sangat penting untuk dilakukan pelatihan mubaligh remaja bagi siswa-siswa di kota Palopo. agar memahami tentang cara islam untuk mencegah kenakalan remaja dan perilaku menyimpan yang berujung pada tindakan pelanggaran (kriminalitas), sekaligus dapat mencetak Muballiqh (dai') remaja sebagai usaha kaderisasi generasi muda Islam dalam mengatasi krisis mubaligh (ulama) yang berperan penting dalam menyampaikan pesan dakwah tentang ajaran Al-Qur'an dan AsSunnah baik di sekolah-sekolah maupun di mimbar-mimbar Masjid agar pelatihan tersebut memiliki arah (road map) dalam menyampaikan dakwahnya.

Ada dua pendekatan yang digunakan dalam kegiatan ini sebagai upaya mencegah dan mengatasi tindakan kriminalitas akibat kenakalan remaja yaitu pendekatan teoritis dan pendekatan empiris atau aplikatif. Pendekatan teoritis dalam pemberian pelatihan yaitu berupa pelatihan mubaligh remaja yang berbasis bimbingan konseling agama Islam dengan upaya pencegahan tindakan kriminalitas akibat dari kenakalan remaja dan perilaku menyimpang berdasarkan Al-Qur'an dan As-sunnah. Sedangkan, pendekatan empiris/ aplikatif dimaksudkan adalah memberikan tata cara atau kiat-kiat yang cerdas dalam berdakwah baik disekolah maupun di masjid-masjid untuk menerapkan materi yang disampaikan pada saat pelatihan sesuai dengan buku materi dakwah yang telah disusun. Adapun tujuan umum yang diharapakan dalam kegiatan ini, yaitu: pertama, pengembangan dan peningkatan pengetahuan, sikap dan keterampilan para remaja (generasi penerus) sehingga memiliki kemampuan untuk mengkaji, merumuskan dan memiliki rasa keperdulian untuk memecahkan persoalan masyarakat berdasarkan sudut pandang Islam. Kedua, terintegrasikan peran perguruan tinggi, pemerintah dan masyarakat dalam upaya menjaga kedamaian ketentraman dan meningkatnya partisipasi masyarakat dalam kerukunan hidup bersama. Sedangkan tujuan khusus yaitu pertama, melalui kegiatan pelatihan mubaliqh remaja ini diharapkan dapat memberikan bekal pengetahuan agama Islam yang baik berdasarkan al-Qur'an dan as-Sunnah sehingga dapat mencegahan kenakalan remaja dan perilaku menyimpang yang berujung pada tindakan kriminalitas.

Dalam pelatihan tersebut juga diharapkan dapat menambah pengetahuan tentang pentingnya memiliki budi pekerti yang agung, menghormati yang lebih tua, menaati guru dan orang tua, serta mampu berbuat baik (amal saleh), mencega kemungkaran dan saling mengingatkan diantara sesama. Berdasarkan penjelasan tersebut maka dapat dirumuskan 
permasalahan yang terjadi di Kota Palopo yaitu Para remaja (siswa) yang telibat tindakan kriminalitas disebabkan karena minimnya pemahaman dan pengetahuan dasar tentang agama Islam dan tidak memahami pandangan Islam tentang upaya mencegah tindakan kriminal dan kenakalan remaja berdasarkan pandangan Islam.

\section{METODE}

Metode yang dilakukan yang dilakukan untuk menjawab persalahan masyarakat tersebut yaitu melalui pelatihan atau ceramah agama, dan praktek ceramah agama yang akan dibawakan oleh remaja yang mengikuti pelatihan. Adapun solusi yang ditawarkan untuk mengatasi permasalahan tersebut yaitu:

a. Memberikan pemahaman dan pengetahuan tentang ayat-ayat dalam Al-Qur'an dan AsSunnah berkaitan dengan tindakan kriminalitas, contoh-contohnya beserta upaya pencegahanan sesuai dengan syariat Islam, baik upaya pencegahan dilakukan oleh individu, masyarakat, maupun upaya pencegahan dilakukan negara.

b. Memberikan pemahaman dan pengetahuan tentang ayat-ayat dalam Al-Qur'an dan AsSunnah berkaitan dengan kenakalan remaja dan perilaku menyimpang, contoh-contohnya beserta upaya pencegahanannya sesuai dengan syariat Islam, baik upaya pencegahan dilakukan oleh individu, masyarakat, maupun upaya pencegahan dilakukan negara.

c. Memberikan pemahaman dan pengetahuan tentang ayat-ayat dalam Al-Qur'an dan As-sunnah berkaitan dengan akhlak yang terpuji (moral), budi pekerti terutama akhlak kepada guru yang mengajarkannya dan pengabdian kepada kedua orang tua yang telah melahirkannya.

d. Memberikan pemahaman dan pengetahuan tentang ayat-ayat dalam Al-Qur'an dan As-sunnah berkaitan materi dasar agama Islam dan pentingnya berbuat baik kepada sesama, serta menjauhi perbuatan keji (mungkar) dalam kehidupan individu, keluarga, bermasyarakat, berbangsa, dan bernegara.

Luaran yang paling mendasar dari kegiatan ini adalah lahirnya kader-kader mubaliqhmuballigha para remaja yang melanjutkan regenerasi dan kaderisasi dakwah yang menyampaikan pentingnya berbuat kebaikan kepada sesama, menjauhi tindakan kriminal dan kenakalan remaja serta menyampaikan kepada yang lain tentang bahaya tindakan kriminalitas dan kenakalan remaja serta sanksi yang diperoleh dari perbuatan tersebut.

\section{PEMBAHASAN}

\section{PELAKSANAAN KEGIATAN}

Adapun langkah-langkah yang digunakan untuk melaksanakan solusi atas permasalahan di atas yaitu sebagai berikut:

\section{Tahapan persiapan}

Pada tahapan ini digunakan untuk menyiapkan perlengkapan yang dibutuhkan dalam pengabdian bagi masyarakat.

2. Penyelenggaraan Pelatihan,

Kegiatan pelatihan yang meliputi: 
a) Penjelasan dalam Al-Qur'an dan As-Sunnah berkaitan dengan tindakan kriminalitas, contoh-contohnya beserta upaya pencegahanan sesuai dengan syariat Islam, baik upaya pencegahan dilakukan oleh individu, masyarakat, maupun upaya pencegahan dilakukan negara.

b) Penjelasan dalam Al-Qur'an dan As-Sunnah berkaitan dengan kenakalan remaja dan perilaku menyimpang, contoh-contohnya beserta upaya pencegahanannya sesuai dengan syariat Islam, baik upaya pencegahan dilakukan oleh individu, masyarakat, maupun upaya pencegahan dilakukan negara.

c) Penjelasan dalam Al-Qur'an dan As-sunnah berkaitan dengan akhlak yang terpuji (moral), budi pekerti terutama akhlak kepada guru yang mengajarkannya dan pengabdian kepada kedua orang tua yang telah melahirkannya.

d) Penjelasan dalam Al-Qur'an dan As-sunnah berkaitan materi dasar agama islam dan pentingnya berbuat baik kepada sesama, serta menjauhi perbuatan keji (mungkar) dalam kehidupan individu, keluarga, bermasyarakat, berbangsa dan bernegara

3. Tahapan praktek

Pada tahapan ini yaitu berkaitan dengan berbagai hal yang telah dipelajari dari pelatihan dengan pendampingan dan supervisi, baik di sekolah-sekolah maupun di masjidmasjid sebagai upaya untuk menyampaikan bahaya tindakan kriminalitas dan kenakalan remaja serta sanksi yang diperoleh bila melakukan pelanggaran.

4. Evaluasi kegiatan

Evaluasi kegiatan yang dilaksanakan untuk mengevaluasi seluruh kegiatan yang telah dilaksanakan sebagai pertanggung jawaban sosila atas kegiatan.

\section{Pendekatan Kegiatan}

Adapun metode pendekatan yang ditawarkan untuk menyelesaikan persoalan tersebut adalah metode ceramah dan tanya jawab (diskusi) antara peserta pelatihan dengan narasumber (tutor) serta metode aplikasi (dakwah). Metode ceramah digunakan pada saat memberikan ceramah atau penjelasan tentang ayat-ayat Al-Qur'an dan As-Sunnah yang berkaitan upaya pencegahan tindakan kriminal akibat kenakalan remaja. Metode tanya jawab atau diskusi digunakan saat sesi diskusi pada agenda pelatihan. Sedangkan, metode aplikasi/ praktek (dakwah) akan dilakukan di beberapa masjid di kota Palopo.

Melalui pesan dakwah berbasis bimbingan konseling agama Islam yang disampaikan oleh para siswa tersebut, diharapkan tingkat kenakalan remaja dan perilaku menyimpang oleh sebagian remaja dan anggota masyarakat dari waktu ke waktu semakin berkurang. Adapun partisipasi mitra dalam kegiatan ini yaitu sebagai berikut:

1. Keterlibatan para guru Agama Islam untuk mengarahkan siswa-siswinya untuk ikut dalam pelatihan mubaligh-muballigha remaja yang berbasis bimbingan konseling agama Islam.

2. Menyampaikan berbagai kekurangan pengetahuan dan pemahaman siswa-siswa Kota Palopo tentang ajaran Al Qur'an dan Al Hadits kepada penyuluh dan pelatih. 
3. Ikut aktif dalam kegiatan tanya jawab atau diskusi untuk mengetahui dan memahami tentang ajaran Al Qur'an dan Al Hadits yang berkaitan dengan upaya pencegahan tindakan kriminalitas dan kenakalan remaja.

4. Ikut melatih dan terlibat (Guru Agama Islam) dalam mengembangkan keterampilan berdakwah mulai dari simulasi dakwah sampai benar-benar berdakwah dibeberapa masjid-masjid di Kota Palopo agar para siswa-siswa tersebut terampil berdakwah di tengah-tengah masyarakat dalam rangka memberikan penyadaran tentang bahaya tindakan kriminalitas akibat kenakalan remaja dan perilaku menyimpang.
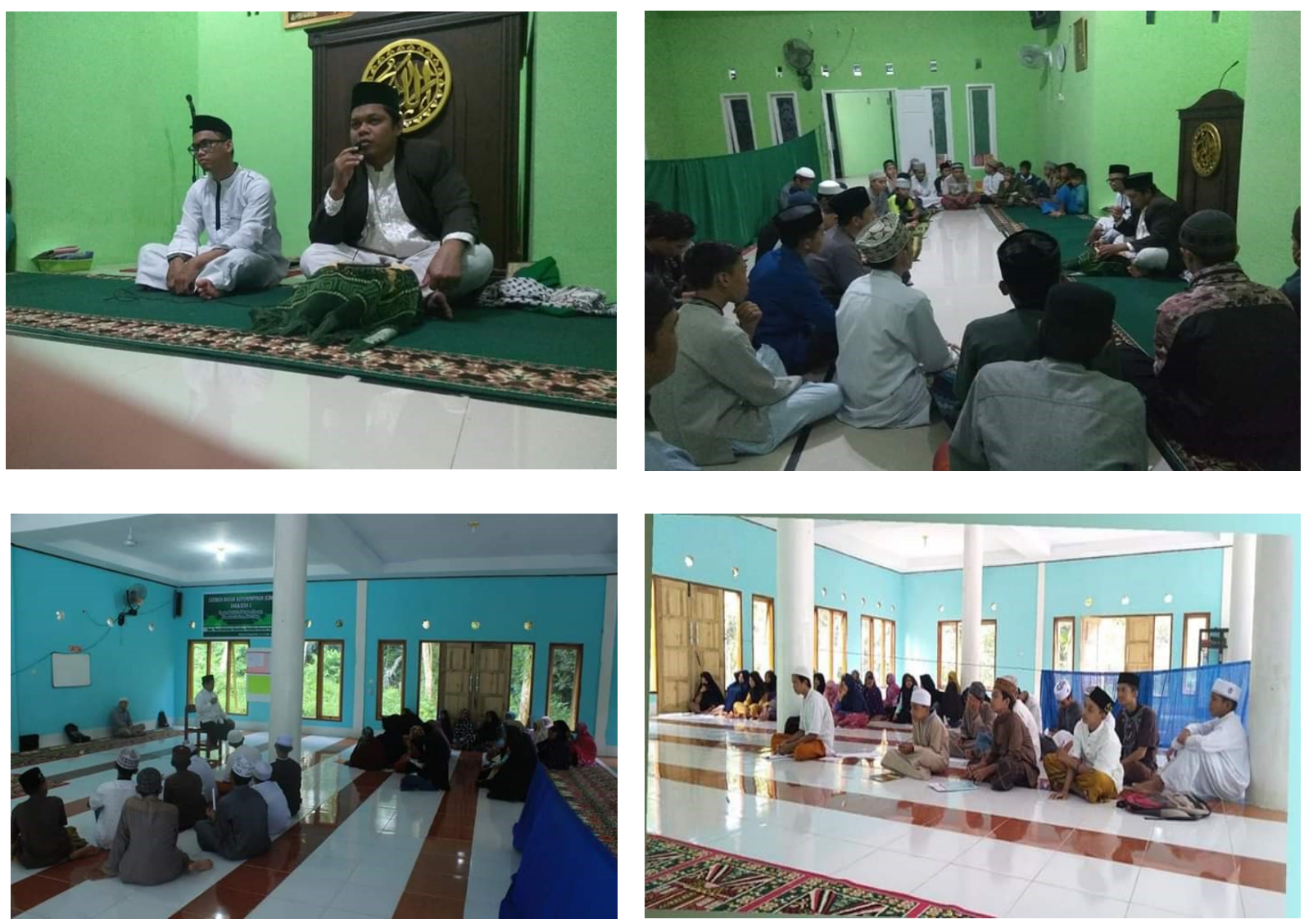

Gambar 2. Pelaksanaan Kegiatan di Dua Masjid (Masjid Al-Hidayah Cakalang Kec.Wara Timur dan Masjid Al-Mujahidin Purangi Kec. Sendana Kota Palopo)

\section{SIMPULAN DAN SARAN}

Berdasarkan uraian di atas dapat disimpulkan bahwa kenakalan remaja termasuk perilaku menyimpang dapat merusak dan membahayakan tegaknya sistem sosial. Salah satu upaya pencegahan yang dapat dilakukan sebagai penyelesaian permasalahan tersebut ialah dengan melakukan pembinaan dan pelatihan para remaja yang berbasis bimbingan agama Islam. Langkah-langkah kegiatan pengabdian masyarakat yang dilakukan yaitu tahapan persiapan, penyelenggaraan pelatihan, aplikasi/ praktek, dan evaluasi kegiatan. Adapun saran untuk kegiatan pengabdian masyarakat yaitu dengan merunitaskan kegiatan pengabdian ini yang berdampak pada perbaikan kehidupan masyarakat yang religius dan dapat meminimalisir kenakalan remaja. 


\section{DAFTAR PUSTAKA}

BAPPEDA (Kota Palopo) dan BPS (Kota Palopo). Palopo Dalam Angka 2014. Palopo: BAPPEDA Kota Palopo, 2014.

Hadis, A. Nurhayati. 2008. Psikologi dalam Pendidikan. Bandung: Penerbit Alfabeta.

Herlina, H., \& Kosasih, A. (2016). Penanggulangan kenakalan remaja di SMP Daarut Tauhid Boarding School. SOSIETAS, 6(2).

Lestari, Alia dan Muhammad Hajarul Aswad. Pemetaan Tindak Kriminalitas Di Kota Palopo Tahun 2015. PALITA: Journal of Social-Religi Research. April 2016, Vol.1, No.1, hal. $29-44$

Kartono, Kartini. Kenakalan Remaja. Jakarta: PT. Raja Grafida, 2007

Kementerian Agama Republik Indonesia, 2013. Al-Qur'an dan Terjemahannya. Jakarta: KARI.

Koran Palopo post, 31 Agustus 2016. www.Palopopos.fajar.co.id/2016/08/31/KorbanNarkoba-Ada-yang-Berumur-7-Tahun/. Di akses 27 Januari 2017

Koran Palopo post, 3 Januari 2017.www.Palopopos.fajar.co.id/2017/01/03/Kapolres-prihatinpergaulan-bebas-remaja/. Di akses 27 Januari 2017

Mannuhung, S., \& Tenrigau, A. M. (2018). Manajemen Pengelolaan Masjid Dan Remaja Masjid Di Kota Palopo. To Maega| Jurnal Pengabdian Masyarakat, 1(1).

Putra, Andi Riswandi Buana. "Peran Guru Bimbingan Konseling Mengatasi Kenakalan Remaja di Sekolah." Pedagogik: Jurnal Pendidikan 10.1 (2015): 32-39.

Sukardi, A. (2018). Metode Dakwah dalam Mengatasi Problematika Remaja. AlMUNZIR, 9(1), 13-28.

Unayah, N., \& Sabarisman, M. (2016). Fenomena kenakalan remaja dan kriminalitas. Sosio informa, 1(2).

Yusuf, S. Psikologi Perkembangan Anak dan Remaja. Bandung: PT. Rosdakarya, 2008. 